\title{
ANALISIS PENGARUH TERWUJUDNYA SMART SOCIETY BAGI PENINGKATAN PELAYANAN PUBLIK DI KABUPATEN SITUBONDO
}

\author{
Muhammad Iqbal Anshory ${ }^{1)}$; Yudhistira Harisandi ${ }^{2)}$ \\ ${ }^{1), 2)}$ Universitas Abdurachman Saleh Situbondo
}

\begin{abstract}
Abstrak
Pendekatan "tradisional" yang selama ini digunakan sudah tidak memadai lagi untuk mengatasi permasalahan kota yang kompleks. Esensi pendekatan tradisional ialah memecahkan permasalahan secara "satu per satu" dan ini tidak menyelesaikan permasalahan sebab satu masalah barangkali selesai, masalah lainnya muncul, begitu seterusnya. Oleh sebab itu dibutuhkan pendekatan "serentak" atau pendekatan "simultan" atau pendekatan "integral holistik/terintegrasi" untuk mengatasi persoalan kota yang semakin kompleks, menuju kota masa depan yang diimpikan oleh penduduknya, yang lebih dikenal dengan sebutan konsep smart society atau kota "cerdas" atau kota "impian masa depan". Konsep Smart Society adalah sebuah pendekatan cerdas dalam membangun kota impian yang bersifat "integralistik atau terintegrasi" untuk mengatasi permasalahan kota yang bertambah kompleks seiring dengan jumlah penduduknya yang makin banyak, yang berbanding lurus dengan kebutuhankebutuhannya, ekonomi maupun non ekonomi. Diharapkan dari penelitian ini dapat memberi pengaruh positif dengan adanya teknologi baru dan pembangunan baru bagi masyarakat, dapat mempermuda pelayanan pemerintah terhadap masyarakat.
\end{abstract}

Kata Kunci: Smart Society, permasalahan masyarakat, pelayanan pemerintah

\section{PENDAHULUAN}

Keberhasilan terhadap konsep smart society tergantung dari adanya unsur, diantaranya yaitu ; (1). Kreatif, mengandung arti kemampuan menghasilkan karya yang berguna dan baru, baik pada tataran individu maupun organisasi (Schilling, 2013), (2). Inovatif, mengandung arti implementasi praktis dari sebuah ide menjadi sebuah alat atau proses baru yang bermanfaat bagi individu, organisasi, dan masyarakat (Schilling, 2013; Fontana, 2011). Kedua unsur tersebut harus terwujud dan terintegrasi kedalam sebuah sistem penataan kota. Implementasi konsep smart society akan berjalan lebih efektif apabila pemerintahan kota/kabupaten dalam merancang kota/kauipaten impian masa depan menggunakan kerangka layanan berbasis IT.

Oleh karena itu kajian ini berusaha menjelaskan terhadap konsep smart city dalam konteks mewujudkan smart society secara intergratif terhadap masyarakat secara prima sebagai obyek pelayanan publik di Kabupaten Situbondo. 
Sehubungan dengan sedang berkembangnya konsep Smart City. Pemahaman terhadap konsep Smart Society akan menjadi sebuah terobosan baru dalam penyelesaian-penyelesaian masalah yang terkait dengan kepentingan publik di Kabupaten Situbondo yang pada akahirnya dapat meningkatkan performa partisipasi dan pemberdayaan masyarakat di kabupaten Situbondo.

Rumusan permasalahan pada penelitian ini secara spesifik sebagai berikut :

a. Bagaimanakah peran dan fungsi para pihak yang terkait untuk mewujudkan Smart Society di Kabupaten Situbondo ?

b. Mengindetifikasi prospek dan potensi untuk menuju terwujudnya smart society sebagai bagian dari kota cerdas di Kabupaten Situbondo ?

c. Bagaimana desain strategi yang dapat dilakukan untuk meningkatkan dan keberlanjutan terwujudnya smart society sebagai bagian dari kota cerdas di Kabupaten Situbondo (bentuk kebijakan)?

Dalam upaya mendukung keberhasilan terhadap Smart City di Kabupaten Situbondo Tahun 2018, maka ditetapkan tujuan penelitian, yaitu :

a. Menjelaskan peran dan fungsi para pihak yang terkait untuk mewujudkan smart society di Kabupaten Situbondo;

b. Menjelaskan prospek dan potensi untuk menuju terwujudnya smart society sebagai bagian dari kota cerdas di Kabupaten Situbondo,

c. Mendesain format strategi yang dapat dilakukan untuk meningkatkan dan keberlanjutan terwujudnya smart society sebagai bagian dari kota cerdas di Kabupaten Situbondo.

\section{METODE PENELITIAN}

Kegiatan penelitian ini melingkupi dua hal yaitu ruang lingkup wilayah dan ruang lingkup materi. Ruang lingkup wilayah adalah pemerintah Kabupaten Situbondo. Sedangkan ruang lingkup kajian materi meliputi: peran dan fungsi para pihak yang terkait untuk mewujudkan smart society di Kabupaten Situbondo yang bertujuan untuk menuju keberlanjutan pembangunan sebuah kota. 
Data yang digunakan dalam kajian ini berupa data primer yang diperoleh dari hasil wawancara, serta data sekunder dari instansi terkait dan data peran dan fungsi para pihak yang terkait untuk mewujudkan smart society.

Jenis data yang digunakan dalam penelitian ini adalah data sekunder dan data primer. Data sekunder merupakan data yang tidak diperoleh dari sumbernya langsung, melainkan sudah dikumpulkan oleh pihak lain. Metode pengumpulan data dilakukan dengan teknik dokumentasi, yaitu pengumpulan data baku yang diperoleh pada Instansi atau Organisasi yang ada, baik pemerintah maupun swasta (Muslimin, 2002:23).

Lokasi penelitian dilakukan di instansi-instansi pemerintahan yang terkait dengan perkembangan Smart Societi yang ada di wilayah Kabupaten Situbondo. Waktu penelitian dilaksanakan selama tiga bulan yang diawali pada 22 Mei 2018 sampai dengan 23 Agustus 2018.

Analisis data yang digunakan dalam penelitian ini berdasarkan pada rumusan permasalahan sehingga metode analisis data yang digunakan sebagai berikut :

\begin{tabular}{cllll} 
No & \multicolumn{1}{c}{ Tujuan Penelitian } & Metode & \multicolumn{1}{c}{ Sumber Data } \\
\hline 1 & $\begin{array}{l}\text { Menjelaskan peran dan fungsi para } \\
\text { pihak yang terkait untuk mewujudkan } \\
\text { smart society di Kabupaten Situbondo }\end{array}$ & Analisis & $\begin{array}{l}\text { 1. Kuesioner } \\
\text { Stakeholders }\end{array}$ & 2. FGD \\
\hline & $\begin{array}{l}\text { Menjelaskan prospek dan potensi } \\
\text { untuk menuju terwujudnya smart } \\
\text { society sebagai bagian dari kota } \\
\text { cerdas di Kabupaten Situbondo }\end{array}$ & Prospektif & 1.Kuesioner \\
\hline
\end{tabular}

Analisis ini dilakukan untuk mengelola potensi masalah yang diperkirakan akan menghambat peran dan fungsi lembaga pemerintahan kabupaten dalam mewujudkan pendekatan dengan smart society ini akan menjadikan Kabupaten Situbondo menjadi sebuah kawasan yang nyaman, aman, efisien dan berkelanjutan. Analisis partisipan/stakeholder dilakukan untuk menentukan kepentingan-kepentingan yang perlu dipertimbangkan ketika akan mencari solusi terhadap ragam persoalan yang terkait dengan pendekatan smart society ini akan menjadikan Kabupaten Situbondo menjadi sebuah kawasan yang 
nyaman, aman, efisien dan berkelanjutan. Analisis stakeholder meliputi tiga tahap yaitu :

\section{a. Inventarisasi para pihak}

Inventarisasi stakeholder dilakukan dengan metode wawancara secara terbuka dengan orang-orang atau pihak-pihak yang relevan dan memahami suatu masalah. Inventarisasi stakeholder dilakukan dalam bentuk analisis deskriptif-kualitatif. Inventarisasi stakeholder akan memetakan peran dan kepentingan dari masing-masing stakeholder sampel, kemudian dilihat sejauh mana keterlibatan dan kepedulian stakholders tersebut terhadap suatu masalah.

\section{b. Analisis pengaruh dan kepentingan}

Unsur terpenting pada analisis stakeholders adalah penilaian atas kepentingan (interests) serta tingkat pengaruhnya (influence) pada proses penyelesaian suatu. Analisis yang dipakai adalah analisis stakeholder PIL ( $\mathrm{P}=$ Power, $\mathrm{I}=$ Interest dan $\mathrm{L}=$ legitimate $)$ berdasarkan dari kriteria kekuatan, interest dan legitimate stakeholder.

\section{c. Partisipasi}

Partisipasi merupakan proses keterlibatan stakeholders dalam mempengaruhi dan menyelesaikan suatu permasalahan dalam masyarakat. Oleh karena itu tiap stakeholder akan memiliki tingkat keterlibatan yang berbeda-beda sesuai dengan bobot yang dimilikinya. Bobot yang dimaksud adalah tingkat kekuatan (power) dan kepentingan (interest) dari stakeholder terhadap suatu permasalahan dalam masyarakat.

\section{Analisis Prospektif}

Analisis prospektif ini digunakan untuk mempersiapkan tindakan strategis dan melihat apakah perubahan dibutuhkan pada masa depan ( Treyer, 2003). Tahapan analisi prospektif dengan menggunakan metode FGD/lokakarya adalah (1). Menerangkan tujuan studi, (2). Identifikasi criteria, (3). Analisis pengaruh antar faktor,(4). Membuat kedaan suatu faktor, (5). Membangun dan memilih scenario dan (6). Implikasi dari suatu skenario. 
Nilai hubungan antar faktor ditetapkan sebagai berikut : untuk dua faktor yang tidak ada saling pengaruh dibarikan nilai nol, sedangkan bila ada pengaruh antar faktor diberi nilai satu sampai tiga, nilai makin tinggi menunjukan pengaruh makin kuat. Penilaian antar faktor pada analisis prospektif dijelaskan pada Tabel 1

Tabel 1 : Skor atau Nilai Pengaruh Antar Faktor pada Analisis Prospektif (Treyer,2003,Godet, 2000 dan GTZ, 2005)

\begin{tabular}{cll}
\hline Skor & & Arti \\
\hline 0 & Tidak ada pengaruh & \\
\hline 1 & Berpengaruh kecil & \\
\hline 2 & Berpengaruh sedang & \\
\hline 3 & Berpengaruh besar & \\
\hline
\end{tabular}

Tahap selanjutnya adalah membuat keadaan atau state dari faktor kunci. Keadaan harus memiliki peluang sangat besar untuk terjadi. Selanjutnya, dari kedaan ini disusun scenario yang mungkin terjadi dan kemudian dibahas implikasi dari skenario.

\section{HASIL DAN PEMBAHASAN}

\section{Gambaran Umum Wilayah Kabupaten Situbondo}

Kabupaten Situbondo merupakan salah satu Kabupaten di Jawa Timur yang cukup dikenal dengan sebutan "Daerah Wisata Pantai Pasir Putih" yang letaknya diujung timur Pulau Jawa, bagian Utara dengan posisi di antara $7^{\circ} 35^{\prime}-7^{\circ} 944^{\prime}$ Lintang Selatan dan $113^{\circ} 30^{\prime}-114^{\circ} 42^{\prime}$ Bujur Timur. Luas wilayah menurut kecamatan terluas adalah Kecamatan Banyuputih 48,167 km² disebabkan oleh karena luasnya hutan jati di perbatasan antara Kecamatan Banyuputih dan Wilayah Banyuwangi Utara. Sedangkan luas wilayah terkecil adalah Kecamatan Besuki yaitu $2.641 \mathrm{~km}^{2}$.

Kabupaten Situbondo mempunyai batas-batas wilayah dengan kabupaten sekitarnya sebagai berikut:

a. Sebelah utara berbatasan dengan Selat Madura 
b. Sebelah selatan berbatasan dengan Kabupaten Bondowoso dan Banyuwangi

c. Sebelah barat berbatasan dengan Kabupaten Probolinggo

d. Sebelah timur berbatasan dengan Selat Bali.

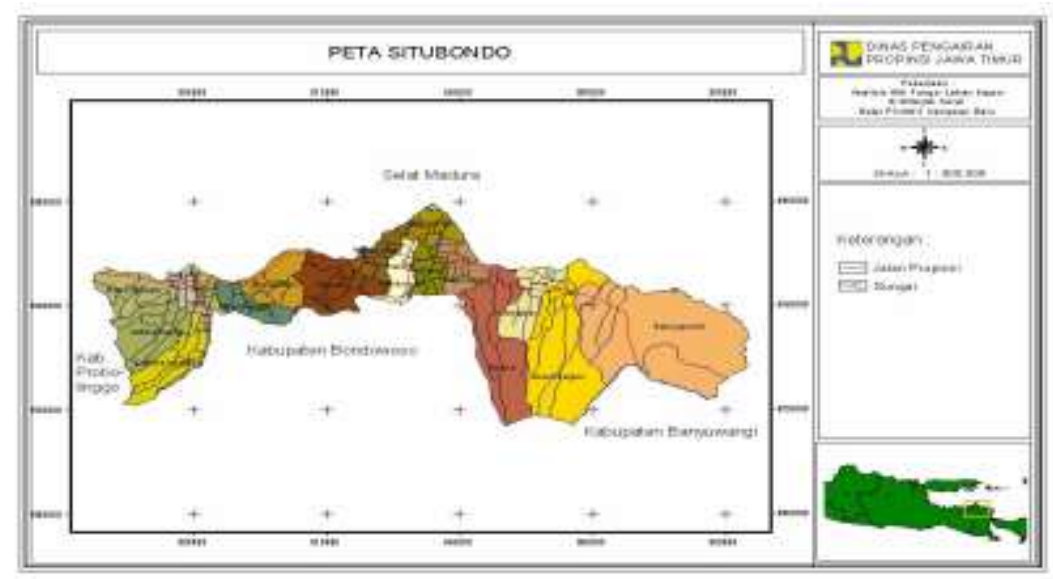

Gambar 1. Peta Kabupaten Situbondo

\section{Hasil Analisis Peran Para Pihak Dalam Smart society}

Berdasarkan kajian pustaka dan penelitian dilapangan, stakeholders yang terkait dalam mewujudkan smartsociety di Kabupaten Situbondo adalah sebagai berikut :

a. Masyarakat yang tinggalnya di wilayah Kabupaten Situbondo.

b. Pemerintah Daerah Kabupaten Situbondo dan jajarannya seperti dinas-dinas yang berkompeten dengan hadirnya pelayanan publik yang mendukung terwujudnya smart society.

c. Lembaga legistatif, sebagai lembaga kontrol yang mewakili rakyat terhadap aktifitas dan produk-produk pemerintah kabupaten, sekaligus sebagai lembaga pembuat peraturan daerah.

d. Pakar/ahli dibidang teknologi informasi, perencanaan daerah dan pembangunan di Wilayah Kabupaten Situbondo. 
e. Pelaku bisnis adalah pengusaha atau praktisi di lapangan yang bergerak dibidang kebutuhan masyarakat luas baik terkait dengan kebutuhan sandang, pangan dan papan.

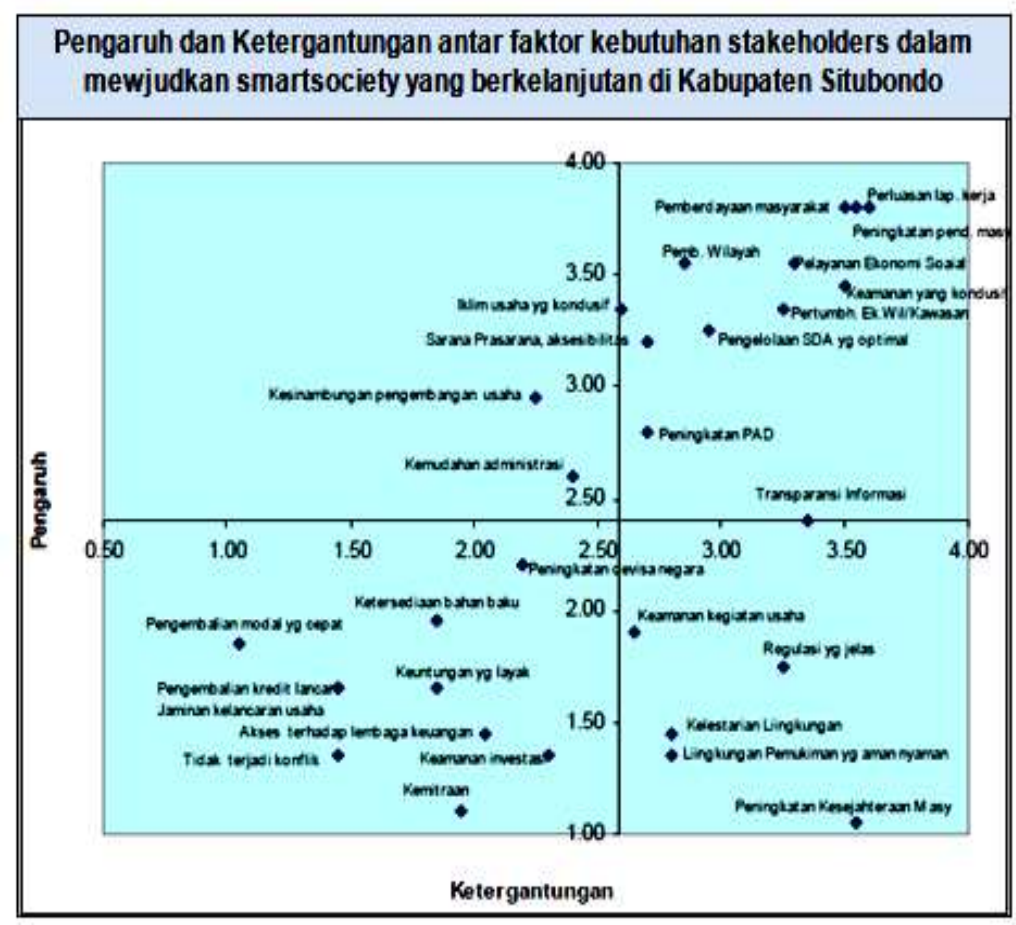

Gambar 2. Pengaruh Ketergantungan faktor kebutuhan stakeholders

Berdasarkan fakta dilapangan maka faktor-faktor pemenuhan kebutuhan stakeholder yang harus diperhatikan dalam mendukung terwujudnya smartsociety secara berkelanjutan. Terdapat 25 faktor yang diidentifikasi yaitu: (1) pertumbuhan ekonomi wilayah/kawasan, (2) peningkatan pelayanan publik masyarakat, (3) peningkatan pendapatan asli daerah, (4) pembangunan wilayah, (5) kemitraan, (6) keamanan yang kondusif, (7) peningkatan devisa negara, (8)pengelolaan sumberdaya alam secara optimal, (9) perluasan lapangan kerja, (10) pengembalian modal yang cepat, (11) kemudahan administratif, (12) jaminan kelancaran usaha, (13) keamanan investasi, (14) regulasi yang jelas, (15) keuntungan yang layak, (16) ketersediaan informasi pasar, (17) iklim usaha, (18) pelayanan ekonomi dan sosial, (19) informasi sarana dan prasarana wilayah, (20) 
lingkungan pemukiman yang nyaman, (21) tidak terjadi konflik, (22) akses terhadap lembaga publik, sosial pendidikan dan ekonomi, (23) transparansi informasi, (24) pemberdayaan masyarakat, dan (25) kesinambungan pengembangan usaha. Faktor-faktor tersebut kemudian dianalisis untuk menentukan faktor kunci mendukung terwujudnya smart society secara berkelanjutan di Kabupaten Situbondo berdasarkan formulasi permasalahan dan kebutuhan stakeholder.

Hasil penggabungan pendapat kelompok stakeholders yang terlibat diperoleh aktor yang berkepentingan dalam mendukung terwujudnya smart society secara berkelanjutan di Kabupaten Situbondo adalah PEMDA sebagai instansi teknis yang sangat terkait dengan mendukung terwujudnya smart society, aktor berikutnya adalah LSM, Perguruan Tinggi/Lembaga Penelitian dan aktor yang terakhir adalah Masyarakat.

\section{Hasil Analisis Propek Dan Potensi Smart Society}

Visi setiap pemerintah daerah selain memiliki dimensi internal (cita-cita yang yang akan diwujudkan) akan selalu berkaitan dengan sejumlah aspek eksternal, terutama yang berkaitan dengan tuntutan pemenuhan berbagai aspek relasi antar anggota masyarakatnya. Adalah merupakan suatu fakta bahwa terdapat desakan dari perkembangan persepktif kebijakan publik yang mengharuskan setiap pemerintah daerah untuk menjamin terselenggaranya pelayanan publik yang harus mempunyai karakter, diantaranya yaitu : Partisipasi (Participation), Aturan hukum (Rule of law), Transparansi (Transparency), Daya tangkap (responsiveness), Berkeadilan (Equity), Efektivitas dan efisien (Efektiveness and efisiency), Akuntabilitas (Accountability) dan Visi Strategi (Strategi Vision). (Leer, 1999). 


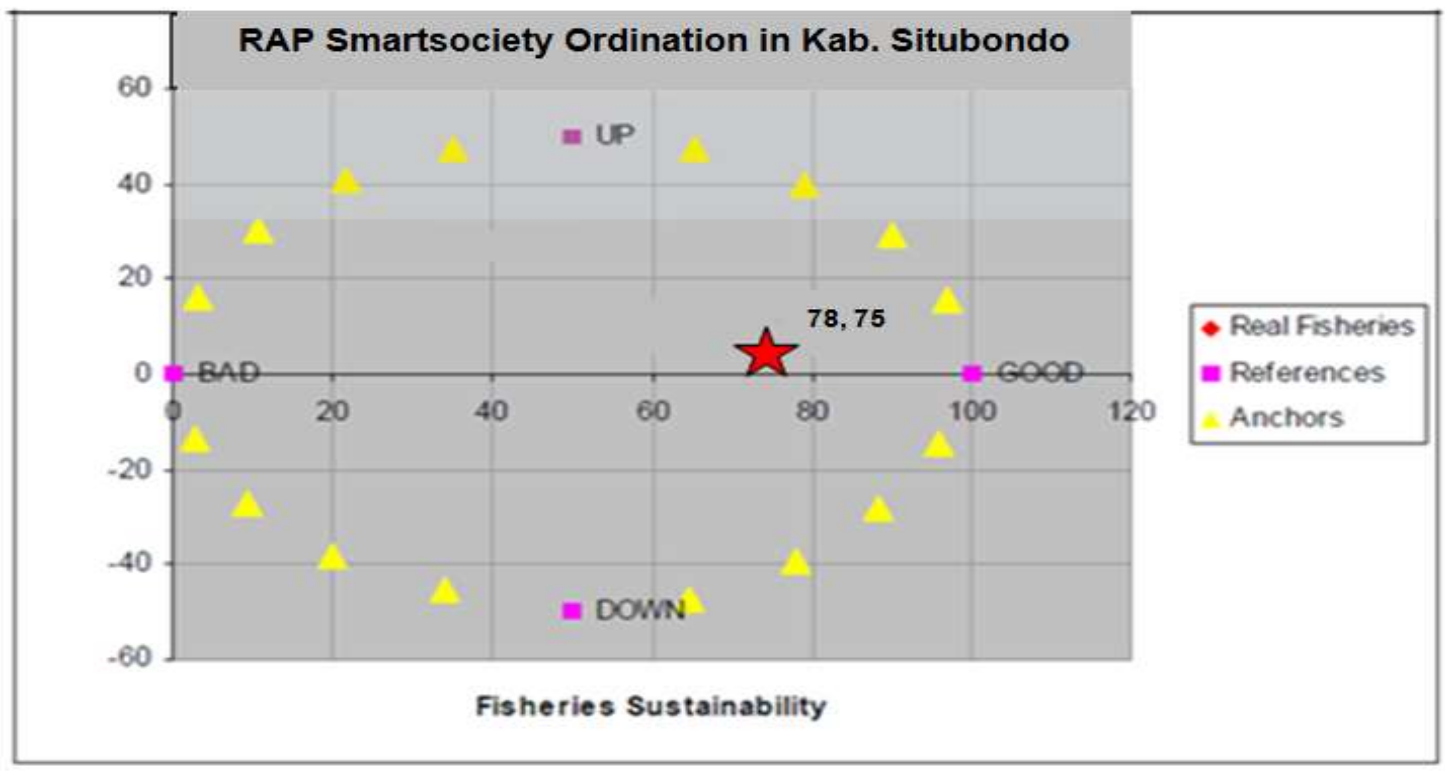

Gambar 3. RAP Smart Society Ordination in Kabupaten Situbondo

Berdasarkan hasil analisis MDS dengan Rap-Fish for Smartsociety, diketahui nilai potensi dan prospek mewujudkan smart society di Kabupaten Situbondo yaitu sebesar 78,75. Hal tersebut menunjukkan bahwa potensi dan prospek mewujudkan smart society di Kabupaten Situbondo berada pada status cukup berpotensi dan berprospek. Indeks potensi dan prospek mewujudkan smart society di Kabupaten Situbondo dapat dilihat pada gambar dibawah.

Selanjutnya setelah dilakukan analisis potensi dan prospek mewujudkan smart society di Kabupaten Situbondo dengan alat analisis leverage factor. Hasil analisis Laverage diperoleh dari enam atribut utama, diantaranya yaitu : (1) dimensi manfaat memiliki nilai RMS sebesar 7,85 (2). dimensi efisiensi memiliki nilai RMS sebesar 7,75 (3). dimensi partisipasi memiliki nilai RMS sebesar 7,50, (4). dimensi transparansi memiliki nilai RMS sebesar 8,15, (5). Dimensi Kualitas Sumber Daya Manusia memiliki nilai RMS sebesar 8,25 dan (6). dimensi manajemen perubahan memiliki nilai RMS sebesar 7,60. Hasil dari analisis leverage factor potensi dan prospek mewujudkan smart society di Kabupaten Situbondo dapat dilihat pada gambar 4. 


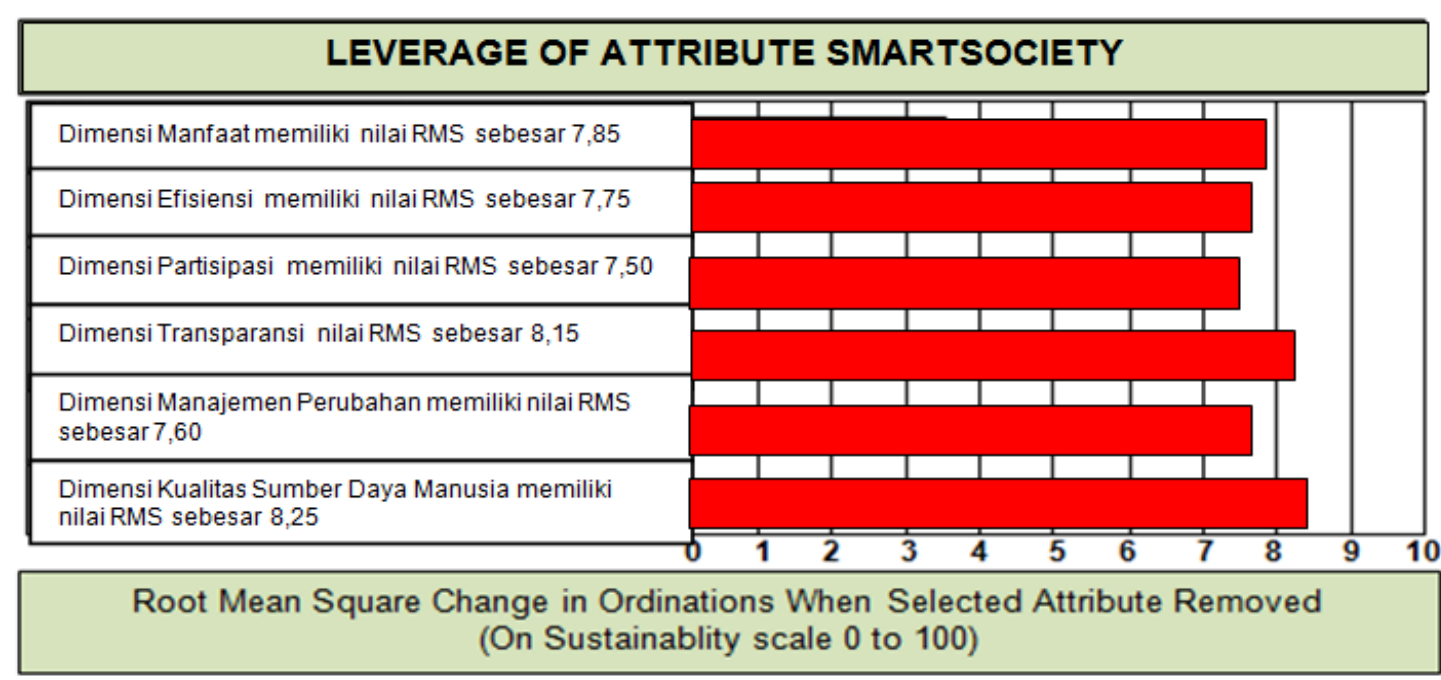

Gambar 4. Hasil analisis Laverage Factor pada potensi dan prospek mewujudkan smart society di Kabupaten Situbondo.

Analisis Monte Carlo yang dilakukan pada keenam dimensi menunjukkan menunjukkan hasil yang baik hal tersebut ditunjukkan dengan mengumpulnya titik hasil pengulangan MDS diatara nilai 75,6-80,20 atau titik ordinasi berada pada posisi yang saling berdekatan.

\section{KESIMPULAN DAN SARAN}

\section{Kesimpulan}

Berdasarkan hasil Analisis Pengaruh Terwujudnya Smart Society Bagi Peningkatan Pelayanan Buplik Di Kabupaten Situbondo dapat disimpulkan diantaranya, yaitu :

1. Hasil penggabungan pendapat kelompok stakeholders yang terlibat diperoleh aktor yang berkepentingan dalam mendukung terwujudnya smart society secara berkelanjutan di Kabupaten Situbondo adalah PEMDA sebagai instansi teknis yang sangat terkait dengan mendukung terwujudnya smart society, aktor berikutnya adalah LSM, Perguruan Tinggi/Lembaga Penelitian dan aktor yang terakhir adalah Masyarakat. Kualitas pelayanan publik menjadi perhatian yang sangat besar. 
2. Analisis potensi dan prospek mewujudkan smart society di Kabupaten Situbondo dengan alat analisis leverage factor. Hasil analisis Laverage diperoleh dari enam atribut utama, diantaranya yaitu : (1) dimensi manfaat memiliki nilai RMS sebesar 7,85 (2). dimensi efisiensi memiliki nilai RMS sebesar 7,75 (3). dimensi partisipasi memiliki nilai RMS sebesar 7,50, (4). dimensi transparansi memiliki nilai RMS sebesar 8,15, (5). Dimensi Kualitas Sumber Daya Manusia memiliki nilai RMS sebesar 8,25 dan (6). dimensi manajemen perubahan memiliki nilai RMS sebesar 7,60. Analisis Monte Carlo yang dilakukan pada keenam dimensi menunjukkan menunjukkan hasil yang baik hal tersebut ditunjukkan dengan mengumpulnya titik hasil pengulangan MDS diatara nilai $75,6-80,20$ atau titik ordinasi berada pada posisi yang saling berdekatan.

\section{Saran-saran}

Hasil Penelitian ini memberikan beberapa rekomendasi untuk Analisis Pengaruh Terwujudnya Smart Society Bagi Peningkatan Pelayanan Publik Di Kabupaten Situbondo, diantaranya sebagai berikut :

1. Mendorong terwujudnya political will yang kongkret, yaitu dengan peningkatan aspek infrastruktur dan sistem manajemen pelayanan publik sudah mendukung konsep smart society dengan fokus pengembangan pada Sumber Daya Manusia melalui pengembangan kompetensi, knowledge, dan kepahaman terhadap teknologi informasi.

2. Merealisasikan instrumen yang dapat membangun dasar pengembangan smart society yang perlu dukungan ketersediaan infrastruktur ICT-nya seperti teknologi broadband fiber, ketersediaan internet kecepatan tinggi (WiFi), dan adanya data center untuk keperluan aplikasi layanan publik bagi Pemerintah Daerah Kabupaten Situbondo.

3. Meningkatkan pengembangan tata kelola pemerintahan yang cerdas dan kompetitif, inovatif, efisien, dan berbasis IT. Melalui pendekatan membangun strategi komunikasi yang efektif dengan para stakeholders. 
4. Meningkatkan berbagai program pelatihan dan pendampingan terhadap pengembangan masyarakat/civil society sehingga menjadi masyarakat yang pintar dan inovatif, kreatif, produktif, serta mampu memanfaatkan potensi keragaman sosial-budaya untuk membangun daya saing Kota Situbondo.

5. Meningkatkan kapasitas dan fasilitas akses terhadap layanan online Pemerintah Daerah Kabupaten Situbondo di seluruh kawasan yang tidak dapat dipungkiri, adanya masalah kesenjangan digital yang tidak semua masyarakat dapat mengakses karena keterbatasan akses internet. Oleh karena itu Pemerintah Daerah Situbondo dapat mengambil inisiatif dengan mendirikan berbagai kios informasi layanan pemerintah di berbagai tempat umum dan counter-counter bagi orang yang tidak punya akses internet khususnya di kawasan perdesaan dan hutan sehingga diharapkan kesenjangan digital ini secara perlahan bisa dikurangi.

6. Meningkatkan fasilitasi layanan yang bisa dilakukan antar badan pemerintah di lingkungan Kabupaten Situbondo. Hal ini disebabkan karena banyak sekali layanan yang berhubungan antara satu badan pemerintah dengan badan lain. Layanan informasi kependudukan misalnya, akan berhubungan dengan layanan pajak, kepolisian, dan semua layanan yang membutuhkan data dan informasi pribadi seseorang. Untuk bisa menjadikan aplikasi dan layanan yang saling terhubung dan berkomunikasi satu dengan yang lain, dibutuhkan berbagai aplikasi yang punya standar interoperabilitas yang sama. Dibutuhkan tidak hanya kerjasama operasional antar badan pemerintah, tetapi juga aplikasi dan teknologi yang memadai.

\section{DAFTAR PUSTAKA}

Abdoullaev, A. (2011). A Smart World: A Development Model For Intelligent Cities. The 11th Ieee International Conference On Computer And Information Technology (Cit-2011). Http://Www.Cs.Ucy.Ac.Cy/Cit2011/.Pdf Batty, M. (2013). Big Data, Smart Cities And City Planning. Dialogues In Human Geography, 3, 274-279. Http://Dx.Doi.Org/10.1177/20438206 13513390 
Briggs, J. (2005). The Use Of Indigenous Knowledge In Development: Problems And Challenges.Progress In Development Studies, 5, 99114.Http://Dx.Doi.Org/10.1191/1464993405ps105a

Bagir Manan, Good Governance, dalam Menyongsong Fajar Otonomi Daerah,Pusat Studi Hukum UII, 2004

Bratakusumah, Otonomi Penyelenggaraan Pemerintahan Daerah, Gramedia, Jakarta, 2002

Dewi, A. (2007). Community-Based Analysis Of Coping With Urban Flooding: A Case Study In Semarang, Indonesia. Master Of Science, Itc.

Dadang Solihin, Pengukuran Good Governance Index. Sekretariat Tim Pengembangan Kebijakan Nasional Tata Kepemerintahan yang Baik BAPPENAS, 2007

ESCAP. (2008). Building Community Resilience To Natural Disasters Through Partnership: Sharing Experience And Expertise In The Region. New York: United Nations.

Folke, C. (2006). Resilience: The Emergence Of A Perspective For SocialEcological Systems Analyses. Global Environmental Change, 16,253-267. Http://Dx.Doi.Org/10.1016/J. Gloenvcha.2006.04.002

Hanif Nurcholis, Teori dan Praktek Pemerintahan dan Otonomi Daerah, Grasindo,Jakarta, 2005

Harsono, HTN, Pemerintahan Lokal dari Masa ke Masa, Liberty, Yogyakarta, 1992

Hardijanto, "Pendayagunaan Aparatur Negara Menuju Good Governance",Makalah TOT Pengadaan Barang atau Jasa, Kementrian PAN, Jakarta , 2000

Hendrikus Triwibawanto Dedeona “Akuntabilitas Kelembagaan Eksekutif", Jurnal Ilmu Adminsitrasi, STIA LAN , Bandung, Vol.4 No 1 Maret 2007

Joko Widodo, Good Governance (Telaah dan Dimensi Akuntabilitas dan KontrolBirokrasi Pada Era Desentralisasi dan Otonomi Daerah), Insan Cendekia,Surabaya, 2001

Lalolo Krina P, "indikator dan alat ukur akuntabilitas, transparasi dan partisipasi" Http// good governance : Bappenas.go.id./informasi.Htm, Sekretaris Good Public Governance. Badan Perencanaan Pembangunan Nasional

Mardiasmo, Otonomi dan Manajemen Keuangan Daerah, Penerbit ANDI, Yogyakarta,2004

Meuthia Ganie Rahman, "Good Governance, Prinsip, Komponen, dan Penerapanya" dalam Hak Asasi Manusia (Penyelenggaraan Negara Yang Baik ),Penerbit Komnas HAM, Jakarta, 2000 
Musacchio, L. W. J. (2002). Cities Of Resilience: Four Themes Of The Symposium (Abstracts). Symposium \#19: Cities Of Resilience: Integrating Ecology Into Urban Planning,Design, Policy, And Management.Washington, Dc: Ecological Society Of America.

Nam, T. P., Theresa A. (2011) Smart City As Urban Innovation: Focusing On Management, Policy, And Context (Icegov2011). 5th International Conference On Theory And Practice Of Electronic Governance 2011 New York. 185-194. Http://Dx.Doi.Org/10.1145/2072069.2072100

Pelling, M. (2003). The Vulnerability of Cities: Natural Disasters and Social Resilience, Earthscan.

Priyatmoko, "Peningkatan Kinerja Eksekutif dan Impelementasi Otonomi daerah “ dalam Syamsudin Haris (ed) Desentralisasi dan Otonomi daerah , LIPI Press, Jakarta, 2005

Sedarmayanti, Good Governance (Kepemerintahan Yang Baik) Dalam Rangka Otonomi Daerah, Mandar Maju, Bandung, 2003

SH. Sarundajang, Pemerintahan Daerah di Berbagai Negara, Pusataka Sinar Harapan, Jakarta, 2001

Syaukani HR., Afan Gaffar dan Ryas Rasyid, Otonomi Daerah Dalam Negara Kesatuan, Pustaka Pelajar, Yogyakarta, 2002

Sari, A. D., Yoppy. (2010). City Resilience Strategy: Semarang's Adaptation Plan In Responding To Climate Change. Semarang: Tahta Undip.

Sariffuddin, S., Susanti, R. (2011). Penilaian Kesejahteraan Masyarakat Untuk Mendukung Permukiman Berkelanjutan Di Kelurahan Terboyo Wetan, Semarang. Makara Seri Sosial Humaniora, 15, 29 - 42. Http://Dx.Doi.Org/ 10.7454/Mssh.V15i1.892

Shaw, R., Srinivas, H., Sharma, A. (2009). Urban Risk Reduction: An Perspective. United Kingdom:Emerald.

Tomordy, M. (2010). Smart Cities Transforming The 21st Century City Via The Creative Use Of Technology, London, Hong Kong, SanFrancisco, Sydney, Arup.

UNISDR. (2009). Terminology On Disaster Risk Reduction. Geneva: United Nations International Strategy For Disaster Reduction (Unisdr).

Vicini, S. B. S., Sanna, A. (2012). The City Of The Future Living Lab. International Journal Of Automation And Smart Technology, 2, 201-208. Http://Dx.Doi.Org/10.5875/Ausmt. V2i3. 134

Yuen, B., Kumssa, A. (2011). Climate Change And Sustainable Urban Development In Africa And Asia. New York: Springer. 